\title{
Divinity, Noēsis, and Aristotelian Friendship
}

John A. Houston

Aristotle's NE X claim that the best human life is one devoted to contemplation (theoria) seems in tension with his emphasis elsewhere on our essentially political nature, and more specifically, his claim that friendship is necessary for our flourishing. For, if our good can be in principle realized apart from the human community, there seems little reason to suggest we 'need' friends, as he clearly does in NE VIII \& IX. I argue that central to Aristotle's NE X discussion of contemplation is the claim that our chief good accords with whatever is 'most divine' in us, viz. our rational nature (NE 1177b12-18). Thus, the best human life involves the excellent exercise of our rational capacities. I distinguish two ways in which human beings flourish through exercising their rationality. The first is in the activity of theoria. The second, I argue, can be found in the virtuous activity of complete friendship (teleia philia). For Aristotle the truest form of friendship is an expression of rationality. It is characterized not merely by our living together, but conversing, and sharing one another's thoughts (NE 1170b12-14). Examining Aristotle's notion of a friend as 'another self' (allos autos), I argue that through friendship human beings come to better know themselves and the world in which they live. Complete friendship involves a (uniquely human) second-order awareness of oneself in another, and through this awareness our understanding of ourselves and the world in which we live is enriched, confirmed, and enjoyed through the presence of other minds. Thus, the highest form of Aristotelian friendship is an intellectual activity through which we attain an analogue of the divine contemplation of the unmoved mover, thereby living with respect to what is most divine in us, but doing so in accordance with our uniquely rational-political nature.

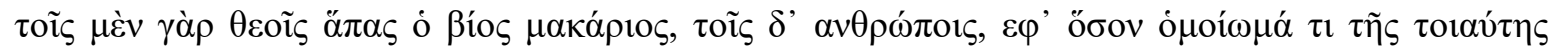

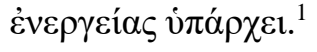

For the life of the gods is blessedly happy throughout, while that of human beings is so to the extent that there belongs to it some kind of semblance of this sort of activity. (NE 1178b25-27) ${ }^{2}$

\section{A Tension in Aristotle's Ethical Thought}

Book X of the Nicomachean Ethics (NE) poses an interpretive problem for scholars of Aristotle's ethical thought. Prior to Book X in the NE Aristotle presents the chief good

\footnotetext{
${ }^{1}$ Aristotle (1962).

${ }^{2}$ Unless otherwise indicated, all translations of Aristotle's Nicomachean Ethics are taken from Rowe, Oxford: 2002. All others are taken from The Complete Works of Aristotle, Princeton: 1984.
} 
of human beings as the good of a political animal, and one that is realized in the context of other political animals. He expends considerable effort in Books I-IX discussing moral and social virtues, relating them to interpersonal relationships and living well in the polis. ${ }^{3}$ Further, he devotes a very long discussion in NE VIII \& IX to the importance of friendship (philia) to eudaimonia. Indeed, no single topic receives more extensive treatment in the NE than friendship. Nevertheless, shortly after concluding his treatment of friendship he argues that eudaimonia consists in a life devoted to contemplation (theōria). But such a life seems compatible with living in contemplative solitude apart from the human community. This presents a puzzle: Are we political beings whose flourishing is realized in relationship with other human beings, or are we such that we can be eudaimonic living alone in contemplation? And if we can flourish living alone, what need do we have for friendship?

In what follows I will look briefly and critically at three different ways scholars have responded to the ostensibly competing conceptions of eudaimonia in the NE. I will then revisit the question of human flourishing in light of Aristotle's discussion of friendship, arguing that, although there remains an element of tension between the life devoted to practical activity and the life devoted to contemplation, this tension does not imply that human beings either can realize their good in isolation. Further, by drawing on several texts within the Aristotelian corpus I will offer reasons for understanding Aristotle's Book X account of theōria as compatible with his emphasis in Books VIII \& IX on the importance of friendship to human flourishing.

\section{Three Responses to the Tension}

There are three ways that scholars have responded to the problem of competing conceptions of eudaimonia in the NE. The first response suggests that there is an unnoticed and unresolved tension in the ethical thought of Aristotle; one which he fails to provide the resources to resolve. The second claims that in Book X Aristotle radically re-conceives the

\footnotetext{
${ }^{3}$ In NE IV for example, he analyzes the virtues of open-handedness (eleutheriotess); munificence (megaloprepeia); greatness of soul (megalopsuchia); and mildness (praotēs). Further, the entirety of Book V is devoted to a discussion of justice. Finally, Books VIII and IX are devoted to the subject of friendship (philia). None of these virtues are possible outside of the human community.
} 
human good, adopting the conception of our flourishing in a life of isolated contemplation. The third attempts to reconcile the two 'competing' accounts of the human good.

I. Thomas Nagel serves as an example of the first response. Nagel argues that Aristotle's ethical thought "exhibits indecision between two accounts of eudaimonia - a comprehensive and an intellectualist account". ${ }^{4}$ The intellectualist account identifies eudaimonia solely with activity of the theoretical intellect, whereas the comprehensive account involves not only the exercise of the intellectual virtues, but also the full range of human life and activities (including the moral virtues, and the importance of interpersonal relationships within the context of the human community). As Nagel puts it, according to the comprehensive account of eudaimonia, Aristotle recognizes the composite nature of the human being "as involving reason, emotion, perception, and action in an ensouled body," whereas according to the intellectualist account he does not. ${ }^{5}$ Nagel suggests that Aristotle's "indecision" between these two accounts persists and is never resolved. He correctly points out that Aristotle insists that our flourishing requires living a life of activity in accordance with what is highest in us (nous), but exactly how this is accomplished or what it finally looks like in our daily activities remains a puzzle. More specifically, how human relationships might finally figure into Aristotle's account of eudaimonia is a mystery for Nagel. He suggests that if one were to persist in asking how the activities of the political community are to fit into the final and complete account of human life that the answer "might be put, somewhat paradoxically, by saying that the comprehensive human good isn't everything and should not be the main human goal". 6 Nagel admits that, "Perhaps this is an unsatisfactory view of human nature and hence an unsatisfactory view of what it is for a human being to flourish". 7 Yet nonetheless Nagel offers that he finds it a "compelling position". 8

\footnotetext{
${ }^{4}$ Nagel (1981), 7. Nagel sees this tension as present in both the Eudemian Ethics and the Nicomachean Ethics.

5 Ibid, 7.

${ }^{6}$ Ibid, 13.

${ }^{7}$ Ibid, 13.

${ }^{8}$ Ibid, 13.
} 
It seems peculiar, at the very least, to suggest that something is both unsatisfactory and compelling. ${ }^{9}$ Furthermore, I am inclined to agree with Nagel: Such a view is unsatisfactory. Nagel's reading seems to suggest that Aristotle has finally failed in what he articulates to be the goal of his project in the NE, viz. identifying and illustrating the chief good of human beings, in order that we might pursue it. ${ }^{10}$ It is certainly possible that Nagel is correct, i.e. perhaps Aristotle was finally unable to present a unified picture of the human good that incorporates every significant aspect of our nature in our flourishing. However, given how unsatisfying such a conclusion is about Aristotle's thought, and the questions it leaves unanswered regarding the role of our political nature in our flourishing, scholars are justified in further pursuing another explanation of this tension in Aristotle's thought.

II. A second response to the problem of competing conceptions of eudaimonia is to suggest that in Book $\mathrm{X}$ Aristotle re-conceives the human good, acknowledging the possibility of our being eudaimon apart from the human community. While such a solution also remains a genuine possibility, it too suggests a serious dissonance in the whole of the Nicomachean Ethics. Not only does this thesis leave us puzzled about the final application of the first nine books of the NE, it leaves a discontinuity with Aristotle's project in the Politics. We must remember that the NE and the Politics comprise a single philosophical work. After arguing in Book $\mathrm{X}$ that eudaimonia consists in a life of contemplation (theōria), Aristotle proposes that we next examine the various forms of government in order to determine which is most conducive to our flourishing as individuals in the human community. Scholars generally recognize the continuity between the NE and the Politics, a continuity that is supported by inter-textual evidence. Aristotle concludes the Nicomachean Ethics with a recognizable segue into the philosophical content of the Politics:

First, then, if there is anything that has been well said on any particular point by our predecessors, let us attempt to discuss that, and then, on the basis of our collected constitutions, try to observe what sorts of things preserve and destroy cities, and what sorts have these effects on each type of constitution, and what the causes are whereby some cities are finely governed and others the opposite. For when we have made these observations, perhaps we shall have a better view, too, on

\footnotetext{
${ }^{9}$ It is peculiar, but not unprecedented. There are some philosophical problems that seem fated to be like this. Philosophical accounts of free will, for example, seem often compelling and yet unsatisfactory.

${ }^{10}$ Aristotle states at the outset of the NE that the goal of his work is to identify the human good and to fill in the details as the work unfolds.
} 
what sort of constitution is best, and how each type is arranged, and what laws and customs it will have. Let us then make a start on the discussion. (1181b16-25)

If Aristotle understood his Book X discussion of theōria to be such a radical reconception of human nature as to require the possibility of being eudaimon apart from the human community, one would hardly expect him to then move into a discussion of something as apparently parochial as the best form of government. Yet this is precisely what he does, and the conclusion of the NE suggests that this is a seamless transition. Aristotle concludes NE X by suggesting that the next natural step in his discussion is to examine political constitutions and "try to observe what sorts of things preserve and destroy cities" and "what the causes are whereby some cities are finely governed and others the opposite" (1181b18-21). Indeed, his entire subsequent discussion in the Politics is underscored by an understanding of human beings as by nature political animals (phusei politikon), and consequently, the notion that our flourishing is achieved in the context of the human community.

III. A third way that scholars respond to the tension is by attempting a reconciliation between the comprehensive practical life and the life devoted to contemplation. This can be done either by attempting to show that Aristotle himself reconciled them, or by proposing a way in which Aristotle might have reconciled them. In her article "The Place of Contemplation in Aristotle's Nicomachean Ethics," Amélie Rorty makes a concerted effort to reconcile Aristotle's account of the relative merits of the comprehensive practical life and the life devoted to contemplation. She argues for a way of reading Aristotle in which these lives need not be 'competitors for the prize'. ${ }^{11}$ Rorty proposes a solution which, although not Aristotle's own, she finds nonetheless 'Aristotelian'. ${ }^{12}$ She argues that contemplation can be broadly construed to include the affairs of the comprehensive practical life. Thus, she claims that for Aristotle nothing about the practical life prevents its also being contemplative, since the practical life itself can be made an object of contemplation. ${ }^{13}$

\footnotetext{
${ }^{11}$ Rorty (1981), 377-378.

${ }^{12}$ Ibid, 378.

${ }^{13}$ Thus she suggests that "the range of contemplation is wider and its effects more far-reaching than has been generally allowed" (ibid, 377).
} 
One advantage of Rorty's position is that it provides for the unity of the later books of the NE. In particular, as Rorty points out, she accounts for the order of the subject matter of Books VII-X. Specifically, Rorty suggests that her interpretation helps to explain the continuity of Aristotle's discussion of pleasure in Book VII, which he resumes in Book X only after a lengthy discussion of friendship in Books VIII and IX:

The discussion of friendship in Book 9 helps show what contemplation can contribute to the comprehensive practical life. By placing that discussion in the middle of his treatment of pleasure, Aristotle shows how virtuous friendship enables a person of practical wisdom to recognize that his life forms a unified, self-contained whole, itself an energeia. The discussion of friendship provides a transition from the Book 7 account of pleasure as the unimpeded exercise of basic natural activities to the Book 10 account of pleasure as the unimpeded exercise of basic natural activitiesan account that makes sense of a person finding pleasure in contemplating the whole of a virtuous life. $^{14}$

Rorty is right to seek an account that demonstrates coherence and unity in the overall text of the NE. Further, her account might go some length in attaining that goal. The problem is that her view fails to match up with Aristotle's explicit description of theōria in NE VI, as well as the reasons that he offers in NE X for suggesting that the life devoted to theōria is the best life for the human being.

In NE VI Aristotle distinguishes two forms of reason exercised by human beings, practical and theoretical. Practical reason is that "by virtue of which we reflect upon things that can be otherwise"; theoretical reason is that "by virtue of which we reflect upon the sorts of things whose principles cannot be otherwise" (NE 1139a6-8). The objects of practical reason include the deliberations and choices which govern the everyday affairs of human life. The objects of theōria are the necessary, unchanging, eternal truths or first principles of reality. Practical reason is productive, i.e. it is concerned with making one's actions conform to one's own best judgments. Theōria, in contrast, is an activity aiming at nothing beyond itself. This distinction between theoretical and practical reason is especially evident in Aristotle's discussion of theōria in Book X: "Again, reflective activity [theōria] would seem to be the only kind loved because of itself: for nothing accrues from it besides the act of reflecting; whereas from practical projects we get something, whether more or less, besides the doing of them" (NE 1177b1-4). Theōria is an intellectual activity in which

${ }^{14}$ Ibid, 378. 
one beholds or gazes upon eternal truths for the sake of knowing them and delighting in that knowledge. Practical reason is deliberative thought about the best course of action for bringing about a desired state of affairs. Theōria is not the process by which we come to know first principles, but the activity of nous beholding known first principles, an activity attended by intense appreciation in the knower. ${ }^{15}$ The life devoted to theōria is that of the knower ever-increasingly appreciating the highest objects of human knowledge. Such a life requires leisure, and seems to be most clearly exemplified by the ousiologist or philosopher. The life devoted to practical affairs and the continual exercise of practical reason does not afford such leisure. It is most clearly exemplified in the legislator, whose concerns are dominated with guiding and administering the affairs of the state in accordance with his or her own best judgments, i.e. it is the life of the politician. ${ }^{16}$ The goods sought by the politician lie beyond the activity of politics, as they are concerned with attaining power, honors, and the general well-being of one's fellow citizens (NE 1177b1315), whereas the telos of theoria consists in the activity itself (X.8). ${ }^{17}$

In Book X Aristotle argues that the best human life is characterized by the activity of theōria. He bases his argument on the premises that our chief good must accord with whatever is most divine in us, and that that which is most divine in us is nous (NE 11771218). The operation of nous is intellectual activity in accordance with the highest (kratistos) knowable objects, (NE 1177a19-21). Aristotle's account of theōria, as well as the reasons he offers for suggesting that a life characterized by this activity is highest for a human being, pose a formidable challenge to Rorty's attempt at synthesizing the life of practical

${ }^{15}$ Theōria is from theōrein, meaning "to consider" or "to gaze upon". The theōros (formed from a combination of thea "a view" and horan "to see") is a spectator. Theöria is sometimes translated as "study". However, I do not prefer this translation since "study" generally carries the connotation of the researcher gathering and memorizing facts. Theoria, however, is not the practice of coming to know, but the activity according to which the wise appreciate what they already know. Thus, I think a more fitting translation of theōria is "contemplation", according to its Latin equivalent "contemplatio" meaning "to gaze intently upon". Unlike the "seeing" we experience with our eyes, the seeing that belongs to theōria does not occur by way of perception, but via the active intellect or nous.

16 The term "politician" has come to acquire rather pejorative connotations in our time. I am here using the term in the classical (and more noble) sense of a leader who acts diligently on behalf of the genuine interests of fellow members of the polis.

17 This is consistent with the pleasure theoria affords because, for Aristotle, the activity and the pleasure never come apart. Pleasure is the completion of the activity. I discuss this point later. 
activity with the life of theoretical activity. Contrary to Rorty's assertion, there is good reason to think the practical and contemplative lives cannot be so easily combined. Given Aristotle's distinction between the aims of practical reason and those of theoretical reason, as well as the distinction between the respective objects of each kind of knowledge, it seems that we cannot extend theōria to include the affairs of the practical life without doing violence to Aristotle's text. The objects of theōria are not the parochial affairs of every day human existence, but the eternal and unchanging truths of mathematics, philosophy, cosmology, and astronomy. Rorty anticipates and attempts to meet this objection:

While objects that do not change at all are paradigmatic cases of what is contemplated, it is also possible to contemplate the unchanging form of what does change. Species meet that requirement: they have no external telos: they are eternal and unchanging (1035b3-1036a1; 1030a6-1031a14). Even when the definition of a species is a pattern of a temporal life, that pattern can be comprehended in one timeless whole. ${ }^{18}$

Here Rorty points out that the activity of practical reason is an activity of the human species, and that, for Aristotle, species are eternal. She then concludes that if we contemplate the nature of human beings and their activities under the aspect of a 'timeless whole', then we are still engaged in theōria. A problem with this response is not that Rorty is saying something false, but that she is changing the subject. When describing the practical life Aristotle is not concerned with the contemplation of the human species under the aspect of eternity, but with the time and energy required of us here and now in living a life devoted to practical affairs. This is evident not only in the examples he provides of the concerns belonging to the practical life, but on his continued insistence that the life of theōria is more leisurely than the life of political activity (EN 1177b4-26). For example, primary among the concerns that Aristotle cites belonging to the life of the politician is that of war: when and where to engage in battle, and how to go about doing so (NE 1177b4-17). Aristotle regards such concerns as presenting impediments (empodia) to theōria (NE 1178b5). And surely he is right to do so: human beings are such that they cannot devote the required intensity of attention to contemplative appreciation of timeless truths while at the same time planning military strategies, balancing the economy, or administering law.

\footnotetext{
${ }^{18}$ Rorty (1981), 379.
} 
For the above reasons I think there remains a tension between the life of practical affairs and the life of contemplation, and I am inclined to think that Aristotle thought so as well: it is simply not possible for a human being to be fully engaged in both types of activities. Further, this tension presents an important question concerning the place of interpersonal relationships in human flourishing. If we accept Aristotle's claim that the highest life is that of theōria, and that the activity of theōria is best exercised in the uninterrupted solitude of the philosopher, there might seem little reason left for devoting our time and energy to cultivating friendships, much less concerning ourselves with the parochial concerns of administering the affairs of the state. Such a matter is not 'merely academic', as it concerns how we ought to live our lives. Indeed the very goal of ethical inquiry for Aristotle is not our merely learning what the good life might look like for the human being, but our becoming good and flourishing. ${ }^{19}$ What, then, are we to conclude in light of Aristotle's Book X discussion of theōria? Is he recommending, as Daniel Robinson jests, an asocial life in which we all "assume the lotus position, live solely on pumpkin seeds, and begin chanting our mantra?"20 I think not. In what follows I argue that, by

${ }^{19}$ Aristotle never fails to emphasize this point. He states it at the beginning and end of the NE (1095a5-6; 1179b3-10). Further, he approvingly cites Plato's idea that the purpose of moral education is to teach us to delight in what is good and to be pained by what is worthless or wicked (NE 1104b11-13). For Aristotle, the person who merely learns what is good and fails to apply this knowledge is like one who listens carefully to his physician's diagnosis, but then fails to do anything prescribed him (NE 1105b15-17). He repeatedly emphasizes that the end of ethical inquiry is not knowledge but action: "The present undertaking is not for the sake of theory [theōria], as our others are (for we are not inquiring into what excellence is for the sake of knowing it, but for the sake of becoming good, since otherwise there would be no benefit in it at all)" (NE 1103b27-29). In this case Aristotle presents theōria as a seeing or knowing that is contrasted with acting and doing. The end of ethical inquiry is not attaining theoretical knowledge about the good human life, but living a life of activity in accordance with virtue. So fundamental is this point that Sarah Broadie suggests that if we miss it we cannot even join Aristotle in his ethical inquiry: "We may examine his ethical doctrines and read and write books about them in order to understand and explain what he is saying. This is not the same as joining him in his ethical inquiry, because those who study him in this way want to know about Aristotle's arguments, whereas Aristotle wants to know about the good life. $<\ldots>$ One possible reason for our wishing to understand Aristotle's arguments is that they may help in a similar inquiry of our own. Aristotle, I imagine, would have regarded this as the best and perhaps as the only good reason for studying his or anyone else's Ethics, and he would not have been at home with someone whose interest is purely academic, even though such scholars are at home with him or his texts" (Broadie (1991), 6). I think Broadie is correct: Aristotle would regard as myopic the attempt to reduce the study of ethics to an analytic enterprise by which we explore logical space (see also EE 1216b21-25 and Pol. 1279b12-15).

${ }^{20}$ Robinson (2004). 
examining Aristotle's account of theōria in conjunction with his treatment of perfect friendship (teleia philia) we can better see how human relationships, and especially friendships, retain an integral role in eudaimonia.

\section{Teleology, Nature, and the Unmoved Mover}

Aristotle's ethical thought is fundamentally teleological, and as such, takes as its starting point the notion of a thing achieving its good. There are two ways in which Aristotle conceives of a thing's seeking its own good. The first can be referred to as 'performative', while the second can be referred to as 'emulative'. ${ }^{21}$ A thing seeks and attains its performative good in performing its peculiar function (ergon) with excellence. ${ }^{22}$ The performative good of a natural object consists in actualizing its natural capacities. For example, a good peach tree is one that engages in its reproductive and metabolic activities, producing good peaches and other trees according to its kind. The emulative good of a natural object consists in its seeking to imitate the unmoved mover (ho prôton kinoun) insofar as possible. According to Aristotle, everything by nature both has (echō) and pursues $\left(d_{i o} k \bar{o}\right)$ something of the divine, and does so insofar as its nature permits (NE 1153b28-34). Thus each living thing, insofar as its nature affords, emulates the eternal contemplative activity (noēsis) of the first mover (De An. 415b1). But, given that different natures possess different capacities, the manner and extent to which each thing imitates the first mover will be different.

The native capacities of plants and non-human animals preclude them from engaging in contemplation: they lack nous. However, Aristotle recognizes in their reproductive activity an analogue of the divine. Through seeking the perpetuity of their species in reproduction, plants and animals emulate the eternal noessis of the unmoved mover. According to Aristotle, the most natural act of a living organism is the production of another like itself: "an animal producing an animal, a plant a plant in order that, as far as its

\footnotetext{
${ }^{21}$ These are my own terms, not those of Aristotle. However, as I try to show, they are true to his account.

${ }^{22}$ It is this sense of something's aiming at its good that Aristotle has in mind when, in the opening

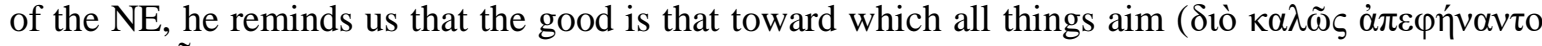

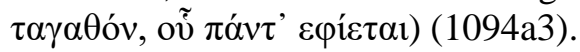


nature allows, it may partake in the eternal and divine. That is the goal toward which all things strive, that for the sake of which they do whatsoever their nature renders possible" (De An. 415a25-415b1). As Richard Kraut points out, "Plants and non-human animals seek to reproduce themselves because that is their way of participating in an unending series, and this is the closest they come to the ceaseless thinking of the unmoved mover". ${ }^{23}$ All natural species imitate the unmoved mover. So, human beings, too, will do so insofar as their nature permits. Indeed, for Aristotle our lives are blessed (makarion) and flourishing (eudaimon) to the extent that they bear a likeness to divine activity: "The life of the gods is blessedly happy throughout, while that of human beings is so to the extent that there belongs to it some kind of semblance of this sort of activity" (NE 1178b25-27). Aristotle is not here suggesting he recognizes the "gods" as traditionally conceived in ancient Greek culture. He clearly rejects the vulgar anthropomorphic notion of the Homeric gods (NE 1178b11-14). Nonetheless, he frequently continues to employ the language of hoi polloi when discussing 'divine' matters. When doing so, he refers to 'the gods' (theoi) as a place holder for that which is best or highest (kratistos). In particular, he refers to 'gods' and 'the divine' when referring to noetic activity. Thus for example in X.8 he develops a link between 'the gods' and what is valuable about the 'intellectually accomplished':

And the person whose intelligence is active [noun energōn], and who devotes himself to intelligence, and is in the best condition, seems also to be most loved by the gods [theophilestatos]. For if the gods have any sort of care for things human, as they are thought to do, it would also be reasonable to suppose both that they delight in what is best and has the greatest affinity to themselves (and this would be intelligence $[$ nous]) and that those who cherish this most, and honour it, are the ones they benefit in return, for taking care of what they themselves love, and acting correctly and finely. And quite clearly, all these attributes belong most of all to the intellectually accomplished person. He, therefore, is most loved by the gods (NE 1179a23-32).

In this passage Aristotle gestures at the traditional conception of the gods as having concern for human things, and links their love of the fine with the value of human noetic activity. ${ }^{24}$ In what follows I distinguish two distinct ways in which human beings exercise

${ }^{23}$ Kraut, Stanford Encyclopedia of Philosophy, (2018): https://plato.stanford.edu/entries/aristotleethics/.

${ }^{24}$ Aristotle's 'theology' is something of a difficult and controversial subject, but it seems that his considered position is that there is ultimately one ho prôton kinoun. Thus he concludes his discussion of the number of movers in Metaphysics $\Lambda$ by approvingly citing Homer's Illiad: 'The rule of many is not good; let there be one ruler' (1076a4). This does not, however, mean that he was 
their rational and noetic capacities to emulate divine activity. The first is found in the contemplation of first principles (theōria), the second, I will argue, is found in perfect friendship (teleia philia).

\section{Theoria and the Limits of Human Nature}

According to Aristotle, the unmoved mover is mind (nous) ceaselessly contemplating mind (Met. 1074b33-34). Human beings imitate the unmoved mover more perfectly than plants and non-rational animals because they possess and can exercise nous. In the Nicomachean Ethics Aristotle identifies nous as the noblest and most divine aspect of our nature. Though we lack the full noetic capacity of the ho prôton kinoun, our possession of nous renders us more like divine than other animals: "for even if it (our nous) is small in bulk, the degree to which it surpasses everything in power and dignity is far greater" (NE 1177b34-1178a2). ${ }^{25}$ Aristotle suggests that our unique nature as rational animals lies in the possession and activity of this authoritative element of nous: "And each of us would seem [doxeie] actually to be this, given that each is his authoritative and better element" (NE 1178a2-3). Furthermore, because the best life for each thing lies in the full expression of its psychic capacities, he understands noetic activity as necessary for eudaimonia. Thus he states, "what belongs to each kind of creature by nature is best and most pleasant for each; for man, then, the life in accordance with intelligence [nous] is so too, given that man is [eiper] this most of all. This life, then, will also be happiest [eudaimonestatos]" (NE 1178a5-8).

There are two ways in which human beings employ their rational capacities to emulate the divine. The first is in theōria. Unlike a divine being, human beings are incapable of directly and continuously contemplating first principles, let alone nous itself. ${ }^{26}$ But in the intellectual activity of theōria we are capable of intermittently contemplating the

a "theist", as some Christian scholars misleadingly suggest. Traditional theism suggests that God takes an interest in human affairs, and Aristotle's unmoved mover is clearly unmoved by such concerns.

${ }^{25}$ See also NE 1160a10-23 and 1168b28-33.

${ }^{26}$ It is not clear to me what Aristotle even means by referring to the activity of nous contemplating nous. I later attempt to offer an analogy that might be helpfully illustrative of his point when discussing the knowledge of a friend as another self (allos autos). 
first principles and eternal truths of cosmology, astronomy and mathematics. Further, a life characterized by such activity is, according to Aristotle, most like the divine (NE 1177b2631). Thus we find him in NE $X$ apparently defending the thesis that the life devoted to theōria is the highest life. Yet within his defense of this thesis there emerges a pressing question: is such a life the life of a human being or that of a god?

But such a life will be higher than the human plane; for it is not in so far as he is human that he will live like this, but in so far as there is something divine [theion] in him, and to the degree that this [being divine] is superior to the compound, to that degree will its activity too be superior to that in accordance with the rest of excellence. If, then, intelligence [nous] is something divine as compared to a human being, so too a life lived in accordance with this will be divine as compared to a human life. (NE 1177b26-31)

When he refers to 'the divine' (theion) in this passage Aristotle is not employing the colloquial Homeric term. Instead he is using theion to focus specifically on nous and noetic activity. This suggests that theion in this passage is much closer to the unmoved mover of his Metaphysics-which Aristotle describes as noêsis noêseôs noêsis (mind contemplating mind, or thought thinking itself) (1074b34) — than to the vulgar anthropomorphic notions of the gods represented in the Homeric tradition. What then does this imply about Aristotle's concluding observation in this passage? Is he suggesting that eudaimonia consists in a life of activity that actually transcends our nature? There seems strong evidence for an affirmative answer to this question in Aristotle's immediate preceding remarks:

One should not follow the advice of those who say 'Human you are, think human thoughts', and 'Mortals you are, think mortal ones', but instead, so far as is possible, assimilate to the immortals and do everything with the aim of living in accordance with what is highest of the things in us. $<\ldots>$ This life, then, will also be happiest. (NE 1177b33-1178a1; 1178a 7-8).

Given his prescription that we seek to live in accordance with what is most divine in our nature, coupled with his above observation that a life in accordance with nous is more divine than human, it might seem that Aristotle suggests that we seek our flourishing in a god-like existence of uninterrupted contemplation. But I think this is incorrect. Aristotle remains persistently sensitive to the fact that our nature renders such a life impossible. The self-sufficiency of the divine nature renders an existence of continuous contemplation possible. But human nature, Aristotle observes, is not self-sufficient (autarkēs) for sustaining continuous contemplation (NE 1178b33-34). As rational animals human beings 
have basic needs that the gods do not have, such as external prosperity and the nourishing and servicing of our bodies (NE 1178b33-35). ${ }^{27}$ Consequently, Aristotle never posits an identity between the eudaimonia of a human being and the blessedness (makarios) of a god. Rather, he is consistently careful to speak of our assimilating a likeness (homoioma) of the divine life, and to recommend that we seek to do so only in so far as is possible (NE 1177b33-34;1178b25-28).

It is true then that, like a divine being, human beings possess nous. Yet, unlike human beings, a divine being is not a hylomorphic compound, and thus has no share in our bodily needs. Nor is a divine being, like a human being, phusei politikon. As Aristotle suggests, it seems laughable (geloios) to envision the gods engaged in the parochial affairs of naturally political beings: "Won't they appear comic, carrying on transactions, returning deposits, and everything like that?" (NE 1178b11-12) Nor, he suggests, is it fitting to imagine them performing acts of generosity. Aristotle makes this final point by posing a rhetorical question: "To whom will they give?" (NE 1178b14) In this deft rejection of the traditional conception of the gods, Aristotle articulates a fundamental difference between the divine nature and human nature: what is fitting for a god might not be fitting for a human being. Hence, he concludes his train of thought with the observation that "Everything about practical doings, if one looks through all the kinds, will obviously turn out to be petty and unworthy of gods" (NE 1178b17-18). ${ }^{28}$

Obviously the same objections cannot be made equally in reference to human beings. In the case of human beings, Aristotle's questions lose their rhetorical force because they admit of an immediate answer: To whom shall we perform acts of justice and generosity? To one another, of course. Unlike a god, who neither lives in community nor realizes its blessedness in community, it is not absurd to imagine human beings engaged in activities that require the presence of others like themselves. The very nature of divine selfsufficiency renders absurd the idea of needing friends. Yet, is it any less absurd to imagine

27 Eudaimonia for human beings is not identical with a maximally blessed state of a divine existence (makaria) because the self-sufficiency (autarkeia) of a human being is not identical with that of a divine being. Divine self-sufficiency entails having no need of external parties to complete or sustain a blessed existence (NE 1178b11-18; see also EE 1245b14-15; MM 1212b34-13a7).

${ }^{28}$ There was already a strong precedent in Greek philosophical thought for rejecting and mocking anthropomorphic notions of the gods. This is especially notable in the fragments that survive from the philosopher, theologian, and poet Xenophanes of Colophon (c.570-c.475 BC). 
a human being living the life of a god than a god living the life of a human being? Surely not, and it seems precisely such an absurdity that Robinson is driving at when he asks if, in Book X, Aristotle is recommending that we live our lives in the lotus position. ${ }^{29}$ Indeed, as Aristotle himself observes, "it would be a strange thing, then, if one chose not one's own life, but that of something else" since "what belongs to each kind of creature is best and most pleasant for each" (NE 1178a4-6). Here Aristotle is arguing that we should seek, insofar as possible, to live divine lives. I am suggesting this imperative cuts both ways: it points not only to the absurdity of a rational being living a bestial life, but also to the absurdity of a rational animal attempting to live the life of a god. What is needed, then, to bridge the gap between human and divine activity, is an account of human self-sufficiency and eudaimonia that properly accommodates the animal and political aspects of human nature without compromising his commitment to the importance of intellectual activity to our flourishing. In what follows I argue that he provides this in his discussion of perfect friendship (teleia philia).

\section{The Noetic Analogue of Virtuous Friendship}

We have seen that for Aristotle a proper account of our flourishing will involve the exercise of our rational nature. Further, we have seen that in the contemplation of first principles human beings can more closely emulate the unmoved mover than non-rational animals. Yet, we have also observed that, due to the limitations of our nature, human beings are incapable of sustaining this activity in the manner of a god. As creatures with bodies, we must tend to our physical well-being; as creatures that are fundamentally social and relational, we have a need to develop and sustain rich interpersonal relationships with other rational beings. Thus far I have said little about the second point. I will now address it in the context of Aristotle's discussion of friendship. I argue that Aristotle's notion of a friend as another self (allos autos) extends his account of human self-sufficiency to include virtuous friends as other selves, and that in friendship human beings can attain a unique noetic analogue of the self-reflexive noèsis of the unmoved mover.

\footnotetext{
${ }^{29}$ Robinson (2004).
} 
Though Aristotle recognizes that human friendships might be in part motivated by considerations of self-preservation, he does not regard such considerations as definitive of the best kind of friendship. He presents perfect friendship (teleia philia) as an activity expressing our rational nature. Specifically, in friendship human beings come to possessand delight in possessing - a greater awareness and knowledge of one another, and thereby, a greater awareness and knowledge of themselves. ${ }^{30}$ The activity by which friends take pleasure in knowing one another is structured and informed by our rational nature. It is not the mere first-order perceptual awareness by which members of a sentient species perceive and gravitate toward others of their kind. Such first-order awareness is evident in the 'gregarious' tendencies we observe in cattle and bees (NE 1170b14; Pol.1253a7-8). Nor is such awareness reducible to the unity of perception or 'common sense' (koinē aisthēsis) by which rational and non-rational animals discriminate between the information provided by their discrete senses. In De Anima Aristotle argues that in addition to the particular senses there must be a single common sense (koine aisthēsis) by which any perceiving animal cognitively distinguishes, organizes, and synthesizes the information provided by its various senses, such as white and black, sweet and bitter, etc. Without this koinē aisthēsis such cognitive discrimination between the different senses is impossible, because it "cannot be effected by two agencies which remain separate; both the qualities discriminated must be present to something that is one and single" (De An. 426b 17-18). But the cognitive capacity for such discretion and synthesis among sensory stimulus is not by itself indicative of rational or noetic activity. As Suzanne Stern-Gillet points out, "unity of perception can obtain in the absence of self-awareness. Perception need not suppose apperception". 31 However, in the perfect friendship of rational agents we find the additional presence of such self-awareness or apperception. In Aristotle's account of perfect friendship there is a description of our rational nature expressing itself through a second-order awareness of ourselves in our friends.

Aristotle highlights this second-order awareness in his culminating argument for the importance of friendship for eudaimonia. The argument appears in NE IX, where he

\footnotetext{
${ }^{30}$ See the following section "Aristotle on Knowledge of the Individual Self" for a discussion what 'knowledge' of oneself or another amounts to for Aristotle.

${ }^{31}$ Stern-Gillet (1995), 19.
} 
reflects on a friend as another self (allos autos). The passage is extensive, and a bit cumbersome, but worth quoting in its entirety:

But if being alive is itself good and pleasant (and it seems to be, also from the fact that everyone desires it, and the decent and blessed people most of all, since for them life is most desirable, and their vital activity is most blessed), and if the one who sees perceives that he sees, the one who hears that he hears, the one who walks perceives that he walks, and similarly in the other cases there is something that perceives that we are in activity, so that if we perceive, it perceives that we perceive, and if we think, it perceives that we think; and if perceiving that we perceive or think is perceiving that we exist (for as we said, existing is perceiving or thinking); and if perceiving that one is alive is pleasant in itself (for being alive is something naturally good, and perceiving what is good as being there in oneself is pleasant); and if being alive is desirable, and especially so for the good, because for them existing is good, and pleasant (for concurrent perception of what is in itself good, in themselves, gives them pleasure); and if as the good person is to himself, so he is to his friend (since the friend is another self): then just as for each his own existence is desirable, so his friend's is too, or to a similar degree (NE 1170a25-1170b10).

In this passage Aristotle points to the cognitive process over and above the koine aisthēsis by which human beings not only recognize $\mathrm{X}$, but are aware that they recognize X: "the one who sees perceives that he sees, the one who hears that he hears $<\ldots>$ " etc. [o

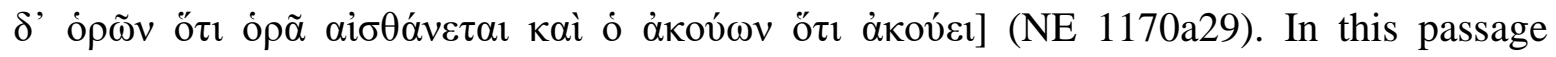
Aristotle explicitly focuses on the role of this cognitive activity in intimate interpersonal relationships. He presents the second-order awareness that belongs to such activity as characteristic of the way friends relate to one another. Unlike non-rational gregarious animals that gravitate toward one another via a combination of first-order perceptual awareness and the herd mentality that follows upon biological necessity, Aristotle points out that human beings are capable of forming social relationships in which they and their counterpart perceive and appreciate perceiving one another, and at the same time know that they are doing so. As Aristotle (somewhat humorously) points out, friendships are characterized not by sharing the same pasture, but by coming to delight in sharing one another's thoughts: "and this [concurrent perception] will come about in their living together, conversing, and sharing their talk and thoughts; for this is what would seem to be meant by 'living together' where human beings are concerned, not feeding in the same location as with the grazing animals (boskēma)" (NE 1170b12-14). Thus Aristotle would highlight not merely the instinctually gregarious tendencies of human beings, but the manner in which our gregarious tendencies are colored by our rationality, and how, in our 
most intimate interpersonal relationships we can obtain a pleasant apperception of ourselves in our friends.

\section{Aristotle on Knowledge of the Individual Self}

Before exploring the nature of this pleasant apperception of a friend as another self, and how it serves as an analogue of the noèsis of the unmoved mover, it is important to first say a few things about Aristotle's concept of the self and the human person, as well as the possibility of our having knowledge of individual selves or persons. When discussing Aristotle's treatment of the human person we must avoid anachronistically imposing onto his thought concerns that were not his own. Aristotle was not a 'personalist' in the contemporary sense of the term. ${ }^{32}$ His writing is not colored with the concerns of the individual interiority of consciousness that arose after the cogito in the modern era. Further, most of his work shows little, if any, concern with the privacy, uniqueness, or irrepeatability of the individual. Neither does he focus on considerations of subjectivity, self-determination, or personal value that preoccupy contemporary personalist philosophers. ${ }^{33}$ Most of his discussion of human beings proceeds from his working out a taxonomy of reality. From this perspective Aristotle's concern is not particular individuals within nature, but the eternal attributes nature itself”. For example, when Aristotle offers 'rational animal' as a definition of a human being, he does so from a scientific perspective. Such a definition arises from the formal and objective consideration of the human species, not from considerations of our individual subjective conscious lives. ${ }^{34}$ In this objective and formal sense there can be no knowledge of the uniqueness of the individual self as such. Theoretical knowledge of an individual as an existing subject is not possible for Aristotle. For, what is individual or peculiar (idion) to each of us is not eternal or immutable, unlike

\footnotetext{
32 The person as an individual existing subject was not a common object of philosophical reflection for the Ancient Greeks. In fact, the Latin and Greek equivalents of 'person' (persona and prosōpon) refer to nothing more than a theatrical mask. The term would later take on more philosophical significance when appropriated by the Patristics in developing the Christian doctrine of the trinity.

${ }^{33}$ Similar observations have been made by Stern-Gillet (1995), 18 \& 21-22.

34 This is especially clear in De Anima, where Aristotle's focus is not the qualitative aspects of individual personal consciousness, but on developing a theory of nous.
} 
the objects of knowledge in theōria. Theōria is an activity by which we contemplate substance (ousia), and knowledge of substance formally considered is knowledge of first principles $(\operatorname{arch} \bar{e})$ and causes (aitia) ${ }^{35}$ Primary substances are individuals, but formal knowledge of substances is generic knowledge of the essence, given in the definition and taken universally. ${ }^{36}$ Nevertheless, despite the fact that when doing metaphysics Aristotle does not focus on considerations of the subjective individual, this does not imply that he cannot or never does accommodate the study of particular existing individuals. Indeed, when pursuing ethical and political inquiry Aristotle's focus concerns not the place of the human being in a proper metaphysical taxonomy, but human beings as individuals acting for specific ends. ${ }^{37}$

In his discussion of friends as other selves Aristotle brings perception and nous together in a manner unparalleled in any other place in his work. Stern-Gillet suggests that in NE IX Aristotle brings together second-order perceptual awareness and awareness of the self as such: "Only in the Nicomachean Ethics are second-order perceptual awareness and awareness of the self qua such brought together. Interestingly enough, the context is a discussion of the benefits uniquely brought about by virtue friendship". 38 Aristotle's discussion of friends as other selves gives us an intelligible sense in which we might claim to know other individual human beings. But this is not only a knowledge of a human being as such, but a rationally and experientially informed second-order knowledge of another human being as the particular human being that they are. Such 'knowledge' comes about

\footnotetext{
${ }^{35}$ See Met. A.1-3 for a discussion of the knowledge of substances, first principles, and causes.

36 (Met. 1003a7-9; 1035b27-30; 1042a21-22;1053b16-18;1060b21-22).

${ }^{37}$ Regarding knowledge of individuals, Christopher Shields points out that for Aristotle "thought is of universals, whereas perception is of particulars (De Anima ii 5, 417b23, Posterior Analytics i 31, 87b37-88a7), though he elsewhere will allow that we also have knowledge of individuals (De Anima ii 5, 417a29; Metaphysics xiii 10, 1087a20)" (Shields 2016). Shields argues that these passages are not contradictory, as Aristotle's goal is to emphasize that thought proceeds at a higher level of generality than perception, due to its "trading in comparatively abstract structural features of its objects;" (Shields 2016). Shields brings his point home when he concludes: "a person can think of what it is to be a stone, but cannot, in any direct and literal sense of the term, perceive this;" (Shields 2016: https://plato.stanford.edu/entries/aristotle-psychology/). Perception discriminates among sensory data, but what it is to be a thing is grasped only by nous. Shields' point could be equally applied to Aristotelian knowledge of individual human beings: we can think of what it is to be a human being, but we cannot in any direct literal sense perceive this.
}

${ }^{38}$ Stern-Gillet (1995), 21. 
through awareness of another person's mental states and familiarity with his or her character. ${ }^{39}$ In NE IX Aristotle suggests that it is possible to gain experiential knowledge of another individual as a result of shared time and activities in which we have come to know, appreciate, and admire their character in an intimate way. ${ }^{40}$ Indeed, such knowledge and appreciation of another's character is the ground of virtuous friendship. Of virtuous friendship Aristotle states,

Such friendship also requires time for the parties to grow acquainted with each other's character; for as the proverb has it, people cannot have got to know each other before they have savoured all that salt together, nor indeed can they have accepted each other or be friends before each party is seen to be lovable, and is trusted, by the other. (NE 1156b26-30) $)^{41}$

Aristotle here suggests that over time and through shared activity human beings can come to know one another, and that such knowledge is the basis of friendship. But this is not the formal knowledge of the individual sub specie aeternitaties that Rorty proposed when attempting to synthesize the life of political activity with that of contemplation. Indeed, knowledge of the person from the cosmological perspective or under the aspect of eternity is not knowledge of the individual as such at all. Rather, in his discussion of friendship Aristotle is referring to a knowledge of another via familiarity with his or her character, and he identifies such knowledge as especially present in teleia philia.

\section{The Pleasant Apperception of a Friend as 'Another Self'}

Complete friends are individual human beings that have, through shared time and experience, become familiar with and come to depend upon each other's character. As

\footnotetext{
${ }^{39}$ I place 'knowledge' in quotes here because, as I have argued above, the knowledge of individual persons belongs neither fully to nous nor is it reducible to first-order perception, but is rather something in between.

${ }^{40}$ See the following section "The Pleasant Apperception of a Friend as "Another Self" for an illustration of how such awareness is attained and shared among friends.

41 The precise origin and meaning of this proverb is uncertain. It is clear, however, that this reference to friends "savouring salt" together is meant to indicate their having a variety of experiences with one another. Salt tends to bring forth subtle differences of flavor, and it preserves what would otherwise rot or spoil. It is also possible that salt here is a metaphor for toil, as the human being secretes salt through the sweat of hard work. Often persons who toil and labor together come to share a unique bond as a result.
} 
Aristotle points out, though the desire for friendship might arise quickly, developing friendship requires time. For, the parties must become acquainted with each other's character, and only thereby can they come to trust each other (NE 1156b25-33). In this 'knowledge' of each other's character friends experience a pleasant apperception of one another as they delight in knowing that there is another who is perceiving, understanding, and taking pleasure in understanding the same things as themselves. Indeed, it would seem that in the most intimate of complete friendships individuals can become so familiar with each other's character that they often need not articulate their thoughts in order for them to be known. Between such friends there often occur what I will call 'knowing moments' that either go unarticulated, or are expressed in nothing more than a nudge or a knowing glance, and they are delightful to experience.

Perhaps these knowing moments in friendship are best illustrated through an example. One of the most famous friendships in American history was that between John and Abigail Adams. ${ }^{42}$ It is well known that Abigail was the source of strength, encouragement, and at times gentle correction for John as he worked to formulate the governing principles of a young nation. This famous friendship has been represented in plays, novels, and biographies, as well as in an acclaimed HBO series "John Adams". 43 John is a man of admirable character, and he wants people to know the fact. ${ }^{44}$ Sometimes

\footnotetext{
${ }^{42}$ One might wonder how 'Aristotelian' such an example is, given that Aristotle seemed convinced that women were incapable of complete friendship. Some scholars ignore this feature of Aristotle's thought, while others attempt to explain it away. However, I am inclined to agree with Suzanne Stern-Gillet's assessment that such attempts are ill-advised. She addresses the issue as follows: "As is well known, Aristotle explicitly argued that women were incapable of the highest and best kind of friendship. I take the view that it does not behove commentators to gloss over or attempt to correct such bias of their authors. In this particular matter we must be content with the confidence that, had he lived today, Aristotle would most probably have revised his views on the nature of women. He was, after all, not only mindful of the opinions of the many but also sought to incorporate the views of the wise in his moral philosophy" (Stern-Gillet (1995), 9).

${ }^{43}$ Though this is a fictional representation I think it is helpfully illustrative of the way in which virtuous friends interact with, learn from, and enjoy one another. It is a fine example of art imitating life.

44 To contemporary ears this desire for recognition might seem a mark against John's character, insofar as it suggests an ambition contrary to humility. But Aristotle would not have shared this view. He did not regard humility as a virtue in the way many Christians would later suggest. For Aristotle, the great-souled man (megalopshuchos) is honorable and has an interest in the good of being recognized as such. However, for Aristotle doing what is honorable is more important than being honored. In this sense, Abigail's gentle correction of John is quite Aristotelian.
} 
his eagerness for others to acknowledge his greatness carries him away. In a later memorable moment in the series we find an elderly John once again adamantly relating to Abigail his frustration with the lack of recognition he receives for all of his hard work: "If I had it to do all over again I would be a farming, shoe-making deacon like my father!" 45 His complaint climbs to a crescendo as he blusters about, uninterrupted by Abigail, that is, until their eyes meet. At this moment, in the exchange of a glance, a whole host of things are communicated between the couple: John and Abigail are intimate friends possessing a long shared history in which they have come to know, and delight in knowing, each other's character. Both John and Abigail are aware of John's tendency to seek honors and recognition. What is more, John knows that Abigail knows this about him, and she knows that he knows she knows it. As a consequence of their shared history and intimate knowledge of each other, Abigail is able to convey, in a single glance, a number of things to John: "John, you are doing it again. After all, what is more important here, that you do what is honorable by your fellow countrymen, or that you come to be honored by them? I think you know, John. And I think you know that we both know". All of this is conveyed in the knowing smile of Abigail, and John instantly perceives it. His awareness of the fact is conveyed by his response-silence, a sigh, and a returned smile that acknowledges Abigail's gentle correction. In this exchange John experiences greater self-awareness through the pleasant apperception of himself in his wife. Furthermore, his confidence that he is perceiving himself correctly is reinforced by the fact that what he is seeing is confirmed by the presence of another knower. This is the same 'concurrent perception' (sunaisthomenoi) of what is 'in itself good' (hauto agathon) and 'yielding delight' (hèdomai) of which Aristotle spoke at NE 1170b4-5. Abigail is to John another self (allos autos). But she is not so only in the sense of being another instance of the same species as John, but in the sense that she is another knower known in her particularity by John, and through whom he has come to better know himself. Insofar as Abigail is another knower she is a fellow human being; however, insofar as she is another knower by whom John comes to better know himself, she is his friend.

\footnotetext{
${ }^{45}$ John Adams (2008). Kirk Ellis wrote the screen play for this series, which was based on the book John Adams by David McCullough, Simon \& Schuster: 2001).
} 
I suggest that in these knowing moments of pleasant apperception between virtuous friends we find an activity that stands as an analogue to the noessis of the unmoved mover, and that this analogue helps us to understand the important role that interpersonal relationships retain in Aristotle's account of eudaimonia. However, before arguing for this analogue I need to comment on the relevance of virtue to the experiential knowledge that leads to the pleasant apperception of oneself in a friend. After all, one might wonder whether the vicious could experience it. Aristotle thinks not, and there are two reasons he maintains this. First, the vicious person lacks an integrated and unified self to behold. Second, what the vicious person does behold of his attenuated self is not pleasant to him. For Aristotle 'self' is an achievement term, an honorific title, indicating a psychological cohesion or unity resulting from integration of intents and desires. As Stern-Gillet points out, for Aristotle 'self' "denotes a state of equilibrium between the various parts of the soul, and constitutes an ideal towards which we should strive but which we may not reach". 46 The vicious person's soul, however, is in disarray due to his possessing conflicting desires which pull in opposite directions.

And since they have no lovable qualities there is nothing friendly about their attitude to themselves. Nor, then, do such people rejoice with themselves, or grieve with themselves; for their soul is in a state of faction, and one side, because of depravity, grieves at holding back from certain things, while the other is pleased, the one pulling in this direction and the other in that, as if tearing the soul apart. (NE 1166b16-21)

The faction and internal rebellion of the vicious person's soul renders him in want of a unified and integrated self upon which he can reflect. Moreover, what he does see when he looks upon himself is hateful, and a source of pain. As Aristotle puts it, "the bad person, then, does not appear to be disposed in a friendly fashion even towards himself, because he has nothing lovable about him" (NE 1166b25-26). For the vicious, being alone means the memory of odious things past and the promise of more of the same to come (NE 1166b12-18). Thus the vicious seeks in the company of others a distraction from the person he is (NE 1166b15-17). Aristotle regards friendship to be beyond the capacity of such a person. The bad person is miserable and wretched (athlios), lacking the friendly disposition

\footnotetext{
${ }^{46}$ For Aristotle, the truly vicious person, because his soul is so disordered, does not find himself pleasant. Further, for Aristotle the vicious person is, as Stern-Gillet points out, less of a self, due to the lack of integration and order of his soul (Stern-Gillet (1995), 29).
} 
(philikōs diakeisthai) toward himself that is prerequisite for developing friendship (NE 1166b26-28). Thus Aristotle links virtue to friendship, and so to well-being; and he links vice and self-isolation to incapacity for friendship, and lack of well-being.

\section{Divine Noèsis and the Love that Belongs to Friendship}

In what remains I examine how concurrent perception (sunaisthomenoi) within perfect friendship reflects a uniquely human use of our rational capacities to mimic the noessis of the unmoved mover. To argue for this claim I posit an analogue between divine noèsis and the pleasant apperception of another self within virtuous friendship. To posit an analogue between two things is to suggest that, while not identical, they are relevantly similar. ${ }^{47}$ Thus, I need to say something about the relevant similarities and dissimilarities between the noessis of the divine and the activity by which friends are recognized and experienced as other selves.

As I pointed out at the beginning of this essay, according to Aristotle all things imitate the divine insofar as their nature affords; and human beings are happy to the extent that their lives resemble divine activity (NE 1178b25-27). The highest divine activity is the noèsis of the unmoved mover. This noēsis is the activity of nous self-reflexively contemplating nous (noêsis noêseôs noêsis) (Met. 1074b34). The pleasant apperception in teleia philia by which perfect friends behold themselves in each other is a cognitive activity analogous to the noesis of the unmoved mover. In the activity of friendship we employ our rational capacities to see, enjoy, and reflect upon enjoying, other minds like our own. This seeing is a rational activity by which we come to an ever-increasing knowledge and appreciation of our friends through ourselves and ourselves through our friends. This 'seeing' extends beyond mere perception, as it draws not only on the immediate stimuli of the senses, but combines that stimuli with the knowledge of an individual that is derived

\footnotetext{
${ }^{47}$ In Topics Aristotle recognizes the usefulness of reasoning by analogy for a number of purposes. "The examination of likeness is useful with a view both to inductive arguments and hypothetical deductions, and also with a view to rendering definitions. It is useful for inductive arguments, because it is by means of an induction in particular cases that are alike that we claim to induce the universal; for it is not easy to do this if we do not know the points of likeness. It is useful for hypothetical deductions because it is a reputable opinion that among similars what is true of one is true also of the rest" (Top. 108b7-14).
} 
from a history of shared activity and thought. What is more, there is not only this awareness of the individual, but awareness that this awareness is being mutually shared.

Unlike divine noēsis, the self-reflexive knowledge and appreciation of other minds we experience in friendship does not consist in a direct vision of nous by nous. ${ }^{48}$ Rather, it occurs in accordance with our mode of understanding, which is not divorced from the particulars of experience. It is the seeing and knowing of another mind that comes about as the result of a shared history in which we have come to know and appreciate the thoughts and character of another. By attaining such knowledge, we come to see and hear our own selves reflected in our friends' words, mannerisms, and actions. In the knowing moments of pleasant apperception shared between friends there occurs a rational recognition of another like oneself. This is not merely the awareness of another member of the species to which we belong, but another member that knows us as the particular individual that we are within that species.

This activity represents a stronger analogue to self-reflexive divine noessis than the imitations of the eternal that Aristotle identifies in the reproductive activity of plants and animals, through which they participate in an unending series that approximates unceasing noèsis (De An. 415a25-415b1). ${ }^{49}$ Unlike plants and animals, the divine nature does not reproduce, but it does exercise nous and maintain the cosmos. The pleasant apperception by which friends recognize themselves in each other imitates the self-reflexive contemplation characteristic of divine noessis. Further, while this pleasant apperception of oneself in a friend is not sustained with the perpetuity of divine noessis, it need not be momentary or briefly episodic. It can vary in duration and intensity. Sometimes it occurs just through knowing that we are in the presence of our friends. As rational and gregarious animals, human beings find experience enhanced by the presence of a familiar like-minded individual. We might take as evidence for this the pleasure we take in knowing that we are seeing the same things as our friends, and much in the same way that they do. Consider, for

\footnotetext{
${ }^{48}$ Indeed, the very notion of a direct vision of nous by nous that seems to belong to the activity of noêsis noêseôs noêsis, (which might literally be translated as thinking thinking thinking) seems so abstract as to be beyond our ken. Yet the notion appears to retain some conceptual content for Aristotle when speaking of divine noetic activity (Met. 1074b34).

${ }^{49}$ The series is 'unending' because, for Aristotle, species are eternal. For a detailed discussion and defense of this claim see Lennox (2001).
} 
example, the unique delight that friends take in shared activities such as the mutual enjoyment of a work of art, or a piece of philosophical literature. Unlike a divine being, our experience and understanding of the world, and consequently our understanding of ourselves as perceivers and knowers, is enriched, confirmed, and enjoyed in the company of our friends because through them we know that we are not alone in having it.

So far I have attempted to show that the noetic aspects of complete friendship are analogous to divine noēsis because in perfect friendships human beings, in accordance with their nature, mimic the self-contemplative activity of mind contemplating mind. This is one way we can see how the activity of friendship can accord with what is 'most divine' in our nature, and thus relates to our being eudaimon. There is, however, a less ethereal way to understand how this final knowledge within friendship accords with what is most divine in our nature, and it can be seen without appealing to the admittedly abstract notion of the unmoved mover as noêsis noêsê̂s noêsis. This is the likenesses we discover between the activity of seeing ourselves in our friends and the divine activity of theōria. Like theōria, which produces "pleasures amazing in purity and stability" the second person experience of oneself in a friend is delightful to the rational being. Further, like theōria, it is a rational activity aiming at nothing beyond itself (NE 1177a26). The delight is taken in what is being seen, not in anything further to be accomplished, and this delight signifies the completion of the activity. ${ }^{50}$ This delight obtains not in reference to the process by which we come to acquire such knowledge of ourselves, but in the final activity of actually seeing and knowing ourselves. Although this seeing can certainly assist in reinforcing the stability of virtuous character, Aristotle finally emphasizes not its instrumentality, but its being intrinsically delightful.

Perhaps we can better understand this pleasant apperception of a friend and how its accompanying pleasures bear a similitude to those of theōria by returning once again to the Adams example. When John's diatribe is arrested mid-sentence by the gaze of Abigail, the smile that John returns to her is not a result of his having come to learn something new about himself, but seeing and appreciating something they both already know. In this moment we observe in the couple's reciprocal expressions not the desiderative gaze of the lover for the beloved, but the appreciative gaze of seeing oneself in another through the

\footnotetext{
${ }^{50}$ As Aristotle argues, pleasure is the completion (teleios) of an activity (energeia) (NE 1175a21).
} 
mutual recognition of the particular person that one is. Just as theōria is not the acquiring of knowledge, but the final appreciation of knowledge acquired, so also the apperceptive knowledge of a friend is the final act of rationality in teleia philia. The object of this pleasant apperception is not, as in the activity of theoria, something eternal and unchanging. Nevertheless, it is, insofar as the parties are virtuous, an object of considerable stability and 'stayability'. For Aristotle virtue is not only the most critical element of eudaimonia, it is also the most stable and abiding. Thus one could expect that, the more virtuous one is, the more dependably he or might become a pleasant object of apperception.

My emphasis on the pleasure or delight of this activity should not be understood as an attribution of hedonism to Aristotle. For Aristotle, the experience of pleasure is not the measure of a thing's being good, but the measure of the agent who experiences it: "The pleasure or pain that supervenes on what people do should be treated as a sign of their dispositions [hexeis]" (NE 1104b3). Worthless people take pleasure in worthless things and vicious activities, good people take pleasure noble things and virtuous activities. What an individual finds pleasurable depends a great deal on the habits he or she cultivates. For Aristotle it is possible to learn to take pleasure in various sorts of activities through habituation and repeated exposure. Even horrific bestial activities can come to be experienced as pleasant through "habit" (ethos) or some "disablement" (pērōsis) of an individual (NE 1148b16-17). ${ }^{51}$ Thus it is sufficiently clear that Aristotle has no intention of suggesting pleasure alone is indicative of an activity's being good, much less does he regard pleasure, in any sense, as 'the good'.

However, one might still wonder why the experience of this delightful apperception of oneself in a friend applies only to the virtuous, and is not to be extended to the vicious. After all, might the villain not only delight in his villainous ways, but also in seeing those villainous ways reflected back to him in friend? I earlier responded in part to this question when I suggested that the vicious man's character leaves him dwarfed and atrophied, having less of a self to behold. But more can be said in response to this question on Aristotle's behalf. As is clear from his example of the Black Sea cannibals, Aristotle does not deny the psychological capacity for people to delight in the terrible. So we should not

\footnotetext{
${ }^{51}$ Aristotle cites the cannibalism of tribal people near the Black Sea who are reputed to enjoy surgically removing their young from the womb in order to devour them (NE 1148b20-25).
} 
expect him to deny the possibility of perversely enjoying a similitude of one's own vice in one's friend. However, the fact that it is psychologically possible to experience something as pleasurable tells us nothing of its value. Aristotle clearly regards some pleasures as contrary to our nature, and therefore, ultimately contrary to our flourishing. Determining the normative value of an activity requires understanding its relation to the ends of our nature and our eudaimonia. No culture which devours its young will flourish, no matter how pleasurable the people in that culture might find the practice. Neither will the villain flourish in his villainy, though he disable himself into enjoying it.

Let us then turn to the pleasure that the virtuous take in seeing themselves in their friends. For Aristotle, the good man takes pleasure in seeing himself because he is good, and he accomplishes this in a unique way through his friend:

But as we saw, the good man's existence is desirable because of his perceiving himself, that self being good; and such perceiving is pleasant in itself. In that case, he needs to be concurrently perceiving the friend - that he exists too-and this will come about in their living together, conversing, and sharing their talk and thoughts. (NE 1170b9-13)

Aristotle goes on to link this pleasant apperception of a virtuous friend to being eudaimon:

For the blessed person, if his existence is desirable in itself (being naturally good and pleasant) and so, to a similar extent, is the friend's, the friend too will be something desirable. But what for him is desirable he must have, or else he will be lacking in this respect. So: the person who is to be happy will need friends possessed of excellence. (NE 1170b14-19)

Unlike the noēsis of the unmoved mover, or the activity of theōria, the delightful apperception of oneself in a friend requires the presence of another. As we have seen, Aristotle takes the unique delight that accompanies the pleasant apperception of oneself in a friend as evidence that even the virtuous will need friends if they are to be eudaimon (NE 1170b14-19). This extension of the self in NE IX to the inclusion of one's friends expounds on a distinguishing mark of human self-sufficiency for Aristotle. In this discussion of friends as other selves, Aristotle extends the notion of the individual 'self' (autos) to include one's friend as 'another self' (allos autos), and thus articulates an important distinction between human and divine self-sufficiency (autarkeia). Unlike the unmoved mover, whose self-sufficiency entails noetic perfection in the absence of any external 
party $^{52}$, human self-knowledge is perfected and more thoroughly enjoyed in the company of another. As other selves friends are minded mirrors of one another. In mirroring one another they engage in a uniquely human analogue of divine activity, as they grow in mutual love and knowledge of themselves through one another.

John A. Houston College of Saint Benedict \& Saint John's University

\section{Bibliography}

Aristotle (1962) Aristotelis Ethica Nicomachea, I. Bywater (ed.), (London: Oxford University Press).

Aristotle (1984) The Complete Works of Aristotle, J. Barnes (ed.), (New Jersey: Princeton University Press).

Aristotle (2002) Nicomachean Ethics, C. Rowe (trans.), (Oxford: Oxford University Press).

Broadie, S. (1987) “The Problem of Practical Intellect in Aristotle's Ethics," Proceedings of the Boston Area Colloquium in Ancient Philosophy 3: 229-52.

Broadie, S. (1991) Ethics with Aristotle (Oxford: Oxford University Press).

Kraut, R. (2018) “Aristotle's Ethics,” Stanford Encyclopedia of Philosophy: https://plato.stanford. edu/entries/aristotle-ethics/

Lennox, J. (2001) Aristotle's Philosophy of Biology: Studies in the Origins of Life Science (Cambridge: Cambridge University Press).

Nagel, T. (1981) "Aristotle on Eudaimonia," in Amelie Rorty (ed.), Essays on Aristotle's Ethics (Los Angeles: University of California Press), 7-14.

Robinson, D. (2004) "Aristotle on the Perfect Life," in The Great Ideas of Philosophy. (The Teaching Company, LLC).

Rorty, A. (1981) “The Place of Contemplation in Aristotle's Ethics," in Amelie Rorty (ed.), Essays on Aristotle's Ethics (Los Angeles: University of California Press). 377-94

Shields, C. (2016) “Aristotle's Psychology," Stanford Encyclopedia of Philosophy: https://plato. stanford.edu/entries/aristotle-psychology/

Stern-Gillet, S. (1995) Aristotle's Philosophy of Friendship (New York: State University of New York Press).

${ }^{52}$ EE 1245b14-15; MM 1212b34-13a7; NE 1178b11-18. 